\title{
CD117 and CD34 Staining Patterns in Childhood Benign Mammary Lesions
}

\section{Çocukluk Çağı Benign Meme Lezyonlarında CD117 ve CD34 Boyanma Paternleri}

\author{
Ayper KAÇAR ${ }^{1}$, İrem PAKER ${ }^{2}$, Fatih AKBIYIK ${ }^{3}$, Ata Türker ARIKÖK², Ervin MAMBET ${ }^{3}$ \\ Departments of ${ }^{1}$ Pediatric Pathology and ${ }^{3}$ Pediatric Surgery, Ankara Children's Hematology and Oncology Hospital, ANKARA, TURKEY \\ ${ }^{2}$ Department of 2nd Pathology, Ankara Yıldırım Beyazıt Research and Training Hospital, ANKARA, TURKEY
}

\begin{abstract}
Objective: $\mathrm{CD} 117$ and CD34 are markers that have both been implied in cancer progression in adult breast lesions. This study was conducted in order to create a retrospective documentation and to analyze the expression patterns of these markers on childhood benign lesions along with a comparison with adult breast lesions' staining patterns.
\end{abstract}

Material and Method: Nine fibroadenomas, 2 tubular adenomas, 1 mammary hamartoma, 2 gynecomastias, 1 benign phyllodes tumor were retrieved from pathology archives of two reference centers between 2005-2010.

Results: CD117 staining was identified in the epithelium of all cases in fibroadenoma/tubular adenoma group and focally positive in 1 mammary hamartoma, 2 gynecomastias, and 1 benign phyllodes tumor. CD117 staining was detected in the stroma of 8 cases. Three fibroadenomas, 1 mammary hamartoma, 2 gynecomastias and 1 benign phyllodes tumor lacked stromal labelling for this marker. All cases were strongly and diffusely positive for CD34 except the benign phyllodes tumor case. This case presented marked loss of stromal CD34 staining when compared to the surrounding stroma. Additionally, pseudoangiomatous stromal hyperplasia was noted in 2 gynecomastias and in the peritumoral stroma of benign phyllodes tumor case.

Conclusion: Our study demonstrated that fibroadenoma was the most commonly encountered breast lesion in childhood and that adolescent fibroadenomas showed similar staining patterns for CD117 and CD34 as for adult counterparts. On the other hand, different expression patterns of CD117 and CD34 between adenoma group and the gynecomastias and benign phyllodes tumor group may implicate different mechanisms of development and tumorigenesis among these groups.

Key Words: Adolescent, Child, Breast, CD117 antigen, CD34 antigen
ÖZ

Amaç: CD117 ve CD34'ün yetişkin meme lezyonlarında kanser progresyonunda rolü olduğu bilinmektedir. Bu çalışma nadir görülen pediatrik meme lezyonlarına ait geriye dönük bir dokümantasyon oluşturma ve bu belirteçlerin çocukluk çağı benign lezyonlarındaki ekspresyonlarını gözlemlemek ve erişkin lezyonlarında bilinen paternlerle karşılaştırma yapabilmek üzere kurgulanmıştır.

Gereç ve Yöntem: İki merkeze ait 2005-2010 dönemi patoloji arşivi taranarak 9 fibroadenoma, 2 tübüler adenoma, 1 meme hamartomu, 2 jinekomasti, 1 benign fillodes tümör olgusu çalışmaya alınmıştır.

Bulgular: CD117 fibroadenoma/tübüler adenoma grubundaki tüm olgularda epitelyal pozitivite göstermiş ve 1 meme hamartomu, 2 jinekomasti ve 1 benign fillodes tümör olgusunda fokal olarak pozitif bulunmuştur. Toplam 8 olguda stromal CD117 ekspresyonu gözlenmiştir. Benign fillodes tümör olgusu dışında bütün olgular CD34 ile kuvvetli ve yaygın stromal pozitivite göstermiştir. Bu olguda tümör dışı alanlarda kuvvetli pozitivite mevcutken, tümörde CD34 ekspresyonu gözlenmemiştir. Ayrıca iki jinekomasti olgusunda ve benign fillodes tümör olgusunun peritumöral stromasında pseudoanjiyomatöz stromal hiperplazi izlenmiştir.

Sonuç: Çalışmamızda, çocukluk çağının en sık gözlenen meme lezyonunun fibroadenom olduğu gözlendi. CD117 ve CD34 ekspresyon paternleri açısından selüler ve klasik fibroadenomlar arasında fark saptanmadı. Diğer taraftan adenomatöz lezyonlar ile jinekomasti ve benign fillodes tümörün farklı CD117 ve CD34 boyanma paternleri göstermesi, bu tümörlerin patogenezinde farklı mekanizmaların rol alabileceğini düşündürmüştür.

Anahtar Sözcükler: Adolesan, Çocuk, Meme, CD117 antijeni, CD34 antijeni

Correspondence: Ayper KAÇAR

Department of Pediatric Pathology, Ankara Children's Hematology and Oncology Hospital, ANKARA, TURKEY

E-mail: ayperkacar@yahoo.com Phone: +90 3125969813 


\section{INTRODUCTION}

A mass in the breast regardless of age and gender is a source of almost universal clinical concern with varying degrees of suspicion about a malignant process. The perinatal period, childhood and adolescence are important intervals for breast cancer risk development. Endogeneous estrogen exposure is thought to be highest in utero and exposure to estrogens throughout life plays an important role in increasing breast cancer risk. Some evidence suggests that breast tissue might be more susceptible to carcinogenic influences during early life and adolescence (1).

Fibroadenomas (FA) are the most common breast masses in adolescent women. Although a large scale epidemiologic study has concluded that FAs represent a low long-term risk for breast carcinomas, the incidence of primary breast malignancy is very low in adolescent age group (2). Less than $1 \%$ of all mammary carcinomas are diagnosed in patients less than 25 years old $(3,4)$.

CD117 (c-kit) and CD34 are markers that have been both implied in cancer progression in adult breast lesions (512). The proto-oncogene c-kit encodes a transmembrane tyrosine kinase growth factor receptor. Several investigators report conflicting results concerning its expression especially in malignant breast lesions. Some studies suggest that c-kit may play a role in breast tumor progression with loss of antigen in malignant epithelium (5).

Despite numerous immunohistochemical studies on adult breast lesions, childhood mammary lesions are not clearly described for the expression of these markers.

We have performed a retrospective archive search for childhood breast lesions in two centers and reviewed the literature for CD34 and CD117 expression patterns in benign adult breast lesions and correlated the findings with the findings of adolescent patients in our study. Fifteen breast lesions from 14 adolescent patients were retrieved from pathology archive and stained with CD117 and CD34 in order to define the risk groups and correlate the findings with that of adults.

\section{MATERIAL and METHODS}

Two institutions (Children's Hematology and Oncology Training and Research Hospital, Ankara, Turkey and Dışkapı Yıldırım Beyazıt Training and Research Hospital, Ankara, Turkey) participated in the present study. Cases in the period from 2005 to 2010 were searched and fifteen lesions from 14 patients (12 female, 2 male) with an average age of 16 years (ranging 13-18 years) were found and evaluated for stromal and epithelial expression patterns of CD117 and stromal staining for CD34.
The cases comprised nine FAs ( 3 cellular, 6 simple), 2 tubular adenomas (TA), 1 mammary hamartoma $(\mathrm{MH}), 2$ gynecomastia (GM), 1 benign phyllodes tumor (BPT). The specimens obtained from surgical excision materials except one tru-cut biopsy from a FA and 2 partial mastectomy from 2 GMs.

We defined cellular FAs as lesions of the usual FA morphology, but with an increased stromal cellularity. Entities such as juvenile FA and giant FA were included in this category. We used stromal overgrowth and the low-power view of leaf-like architecture as the main distinguishing feature between phyllodes tumors and FAs. Our single case of phyllodes tumor, which was partly necrotic, was a benign one with a mitotic count of less than 2/10 HPF, presenting low stromal cellularity, low-toabsent nuclear pleomorphism, pushing borders with no stromal overgrowth. The MH case presented 1 FA nodule at the same side simultaneously. The mass was composed of circumscribed dense fibrous tissue with otherwise unremarkable ducts and lobules.

Immunohistochemistry was performed with a peroxidasestreptavidine method on formaline-fixed paraffinembedded tissue using standard protocols. Epitopes were retrieved by heating sections in a microwave oven for 20 min (at $900 \mathrm{~W}$ for $10 \mathrm{~min}, 600 \mathrm{~W}$ for $5 \mathrm{~min}, 300 \mathrm{~W}$ for 5 min) using Tris/EDTA solution $(\mathrm{pH}=8.0)$ for $\mathrm{CD} 34$ and citrate solution $(\mathrm{pH}=6.0)$ for $\mathrm{CD} 117$. Immunophenotyping of samples used ready-to-use mouse anti-c-kit oncoprotein (Novocastra, RT4-CD117, CE/UK) and ready-to-use mouse anti-CD34 (Novocastra, RTU-END, CE/UK).

Staining of blood vessels was used as an internal positive control for CD34 and of stromal mast cells for CD117. When stromal mast cells were unidentifiable, appropriate positive controls were used.

Both markers were evaluated by immunoreactive score (IRS): CD117 for both the epithelial and the stromal components and $\mathrm{CD} 34$ for the stromal component. The percentage scoring categories were defined as 0 , rare-focal groups $(1+),<30 \%$ cells $(2+),>30 \%$ cells $(3+)$. A stromal signal was considered positive, if it displayed equal or greater intensity than that of the benign breast epithelium in the surrounding tissue for c-kit evaluation. Only the spindle fibroblastic cells were counted for stromal c-kit signalling. CD117 positive mast cells were identified as round shaped cells with central round nuclei and granular cytoplasmic staining. A toluidine blue dye was also performed on each case in order to evaluate the mast cell density and shape accordingly in equivocal cases. Spearman's correlation test was used for the statistical analysis. 


\section{RESULTS}

Fifteen lesions from 14 adolescent patients ( 12 female, 2 male) with an average age of 16 years (ranging 13-18 years) evaluated for stromal and epithelial expression patterns of CD117 and CD34 and morphologically (Table I).

CD117 staining was identified in the epithelium of all cases being diffusely positive in FA and TA group and weakly to focally positive in $1 \mathrm{MH}, 2 \mathrm{GMs}$ and $1 \mathrm{BPT}$ (Figure 1). The staining pattern was cytoplasmic and apical in all cases. None of the cases were shown to express membranous or subepithelial staining pattern. There was no difference in expression between cellular FAs and the simple FAs. The cytoplasmic CD117 staining was detected in the stroma of 8 cases being weakly to moderately positive. Three FAs (1 cellular, 2 simple), $1 \mathrm{MH}, 2 \mathrm{GM}$ and $1 \mathrm{BPT}$ were negative for this marker in the stroma. There was a statistically significant correlation between the epithelial and stromal CD117 positivity in all lesions $(\mathrm{r}=0.558, \mathrm{p}=0.031)$.

All cases were strongly and diffusely positive for CD34 but the BPT case (Figure 2). This case presented marked loss of stromal CD34 when compared with the surrounding stroma (Figure 3).

Morphologic examination showed pseudoangiomatous stromal hyperplasia (PASH) in 2 GMs and in the peritumoral stroma of the BPH case (Figure 4). Two FAs, $1 \mathrm{TA}$ and $1 \mathrm{GM}$ case presented typical ductal hyperplastic lesions focally.

\section{DISCUSSION}

There is limited work concerning childhood breast lesions in the literature. In general, most childhood lesions are benign (FA, GM, macromastia). The mesenchymal tumors are relatively more common than in adulthood and malignant tumors are more likely to be secondary or metastatic (rhabdomyosarcoma, hematolymphoid tumors) (4). The data including the published series on pediatric breast lesions are provided in Table II, and a thorough review of the literature has been performed regarding fibroadenomabreast cancer relationship, CD117 and CD34 expressions in various breast lesions paying special attention to childhood cases.

\section{Fibroadenoma-breast cancer}

There are few studies concerning childhood mammary lesions in the literature. The most common malignant lesions are metastases and are usually associated with widespread disease. The most common primary breast malignancy of childhood is malignant phyllodes tumor. Primary breast carcinoma is exceedingly rare in the pediatric age group (13).

In one series of 37 adolescent female patients with breast lesions, ductal carcinoma in situ was found in 2 patients within a fibroadenoma $(4,7 \%)(14)$.

Dupont et al. showed that adult women with FAs have a higher risk for developing breast cancer than women of similar age in the general population (2). In another

Table I: Immunoreactive scores of the cases

\begin{tabular}{|c|c|c|c|c|c|}
\hline & Sex & Age & Epithelial CD117 positivity & Stromal CD117 positivity & CD34 positivity \\
\hline Cellular FA & $\mathrm{F}$ & 14 & +++ & + & ++ \\
\hline Cellular FA & $\mathrm{F}$ & 17 & +++ & ++ & +++ \\
\hline Cellular FA & $\mathrm{F}$ & 17 & +++ & - & +++ \\
\hline FA & $\mathrm{F}$ & 15 & ++ & + & +++ \\
\hline FA & $\mathrm{F}$ & 15 & ++ & - & ++ \\
\hline FA & $\mathrm{F}$ & 14 & +++ & ++ & +++ \\
\hline FA & $\mathrm{F}$ & 15 & ++ & + & +++ \\
\hline FA & $\mathrm{F}$ & 17 & +++ & - & ++ \\
\hline FA & $\mathrm{F}$ & 16 & ++ & + & ++ \\
\hline TA & $\mathrm{F}$ & 14 & +++ & + & ++ \\
\hline TA & $\mathrm{F}$ & 16 & +++ & + & +++ \\
\hline MH & $\mathrm{F}$ & 15 & + & - & ++ \\
\hline GM & $\mathrm{M}$ & 17 & + & - & +++ \\
\hline GM & $\mathrm{M}$ & 13 & + & - & +++ \\
\hline BPT & $\mathrm{F}$ & 17 & + & - & + \\
\hline
\end{tabular}

FA: Fibroadenoma, TA: Tubular adenoma, MH: Mammary hamartoma, GM: Gynecomastia, BPT: Benign phyllodes tumor 


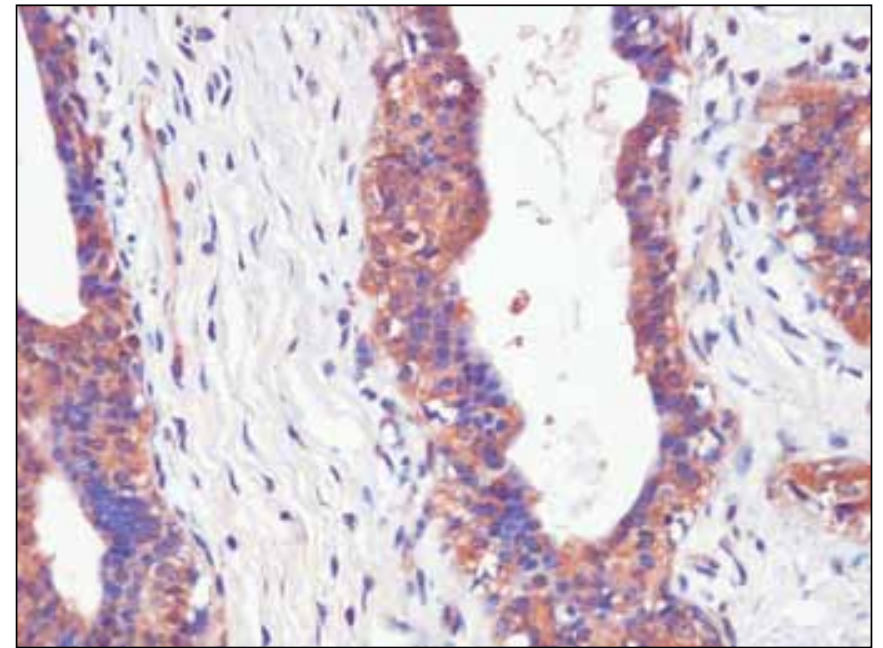

Figure 1: Epithelial and stromal c-kit positivity in FA (x400).

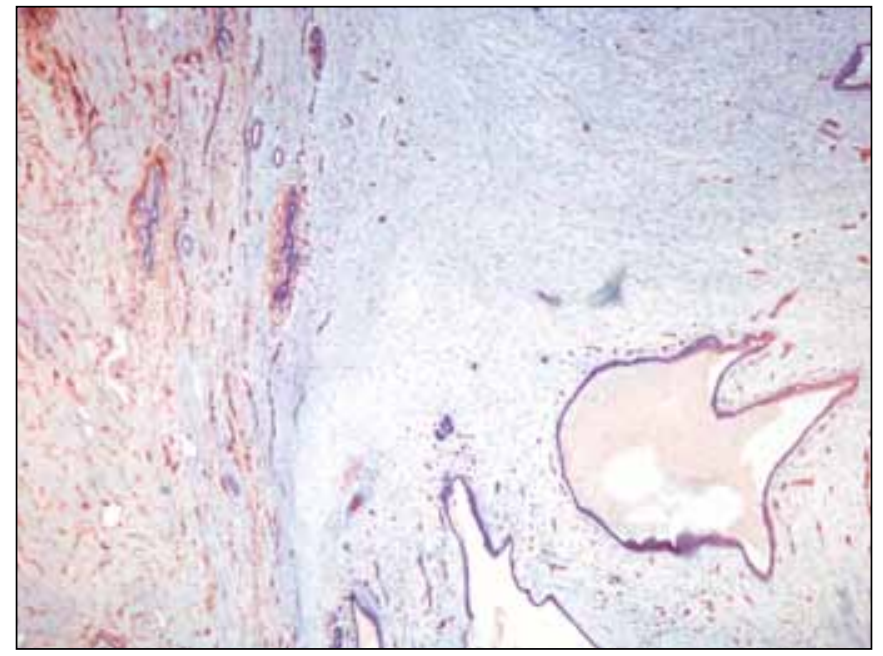

Figure 3: Marked loss of CD34 in benign phyllodes tumor (x100).

study, 9 breast FAs from females of different ages who had a family history of breast cancer were studied; having the same histological structure, the tumors differed in their expression of steroid hormone receptors, in the values of proliferation marker $\mathrm{Ki}-67$ and oncomarker p53. It is concluded that the study of FA may reveal breast carcinoma risk groups (15).

We think that a correlative mammary cancer study has yet to be conducted for adolescents. However, primary breast cancer in adolescents is even a more rare phenomenon. In an adult series, the incidence of cancer within the fibroadenomas was 2,9\% (16). We have seen no epithelial malignancy comprising our cases in the present study. Only one TA (case 11) presented slight ductal epithelial atypia with some loss of myoepithelial cells demonstrated with CK5/6 having 10-15\% proliferation index which was highlighted with Ki-67. This case had a prior $\alpha$-interferon therapy for a cranial giant cell tumor.

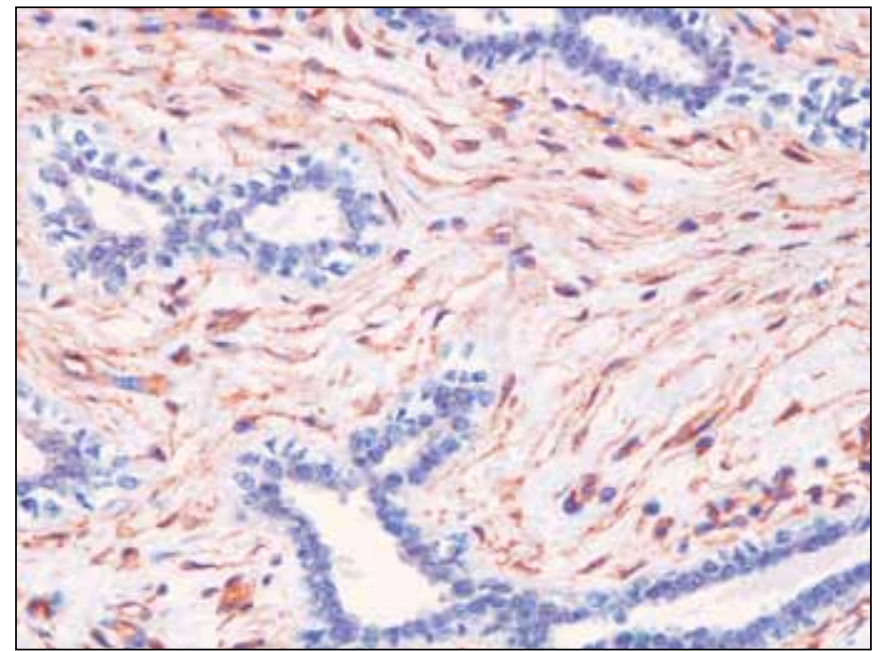

Figure 2: Diffuse CD34 positivity in FA (x400).

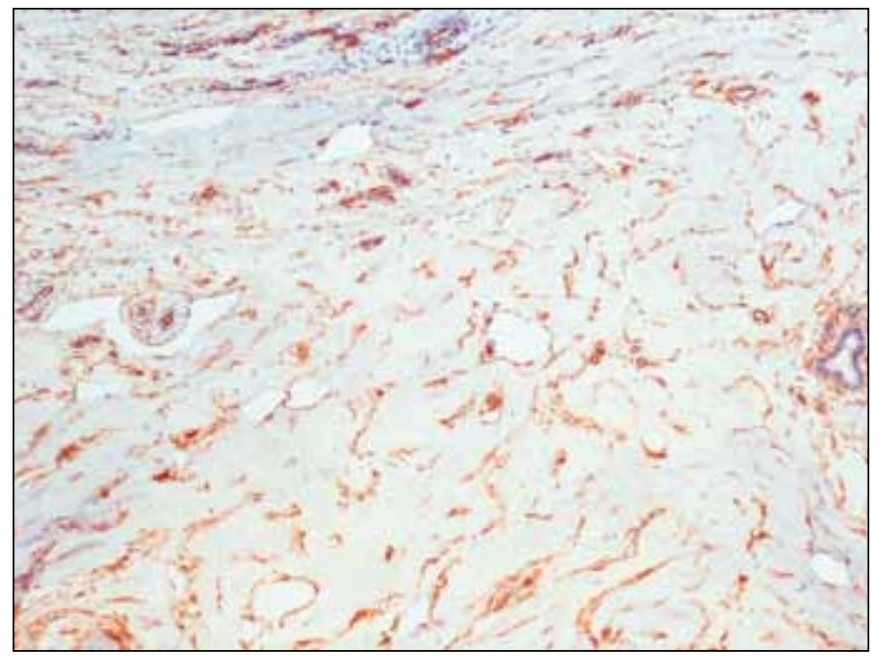

Figure 4: Pseudoangiomatous stromal hyperplasia in peritumoral region of $\mathrm{BPT}(\mathrm{CD} 34, \mathrm{x} 200)$.

\section{CD117-breast cancer relationship and expression in} fibroadenomas

There are contradictory results about the impact of CD117 on breast cancer development in the literature. In one study, CD117 was consistently expressed in normal breast epithelium, variably expressed in benign breast lesions comprising 5 FAs and poorly expressed in breast carcinoma (5).

In another study, CD117 expression was found to correlate with malignancy in breast tumors (6). Most of the FAs in the literature showed positive staining for c-kit in the epithelial component $(5,7)$. In the vast majority of positive tumors, the percentage of positive cells was well over $5 \%$, with large strips of epithelium or entire gland often staining for CD117. None of the FA or PTs were found to be truly positive for stromal c-kit signalling in one study (7). 
Table II: Documentation of pediatric series on mammary lesions

\begin{tabular}{|c|c|c|c|}
\hline Reference (no) & $\begin{array}{l}\text { Total number } \\
\text { of cases }\end{array}$ & $\begin{array}{c}\text { Period of } \\
\text { retrospective search }\end{array}$ & Diagnosis \\
\hline $\begin{array}{l}\text { Pediatr Radiol } 1994, \\
\text { Boothroyd A et al ( } 24)\end{array}$ & 17 & 5 years & $\begin{array}{l}\text { 1. inflammation, 2. GM, 3. precocious } \\
\text { puberty, 4. giant juvenile FA, 5. primary } \\
\text { rhabdomyosarcoma, 6. lymphoma, 7. metastatic } \\
\text { neuroblastoma }\end{array}$ \\
\hline $\begin{array}{l}\text { Eur J Pediatr Surg 1998, } \\
\text { Ciftci AO et al (25) }\end{array}$ & 30 & 25 years & $\begin{array}{l}\text { 1. FA, 2. PT, 3. fibrocystic disease 4. intraductal } \\
\text { papilloma 5. metastatic carcinoma } 6 \text {. fat necrosis }\end{array}$ \\
\hline $\begin{array}{l}\text { Semin Diagn Pathol 1999, } \\
\text { Dehner LP et al (4) }\end{array}$ & 374 & 20 years & $\begin{array}{l}\text { 1. FA, 2. GM, 3. macromastia, } 4 \text {. fibrocystic } \\
\text { changes, } 5 \text {. soft tissue tumors, } 6 \text {. TA, } 7 \text {. cysts, } \\
\text { 8. PT, 9. papillary ductal hyperplasia, } 10 . j u v e n i l e \\
\text { papillomatosis }\end{array}$ \\
\hline $\begin{array}{l}\text { J Indian Med Assoc 2001, } \\
\text { Inder M .et al. (22) }\end{array}$ & 37 & 20 years & $\begin{array}{l}\text { 1. FA, 2. juvenile FA, 3. virginal hypertrophy, } \\
\text { 4. PT, 5. duct papilloma, 6. tuberculosis }\end{array}$ \\
\hline $\begin{array}{l}\text { Acta Chir Belg 2006, } \\
\text { Sonmez K et al (23) }\end{array}$ & 30 & 18 years & $\begin{array}{l}\text { 1. FA, 2. GM, 3. TA, 4. solitary intraductal } \\
\text { papilloma, 5. juvenile papilloma }\end{array}$ \\
\hline $\begin{array}{l}\text { Pediatr Surg Int 2009, } \\
\text { Tea MK et al (14) }\end{array}$ & 37 & 13 years & $\begin{array}{l}\text { 1. FA, 2. fibrocystic disease, 3. in situ ductal } \\
\text { carcinoma }\end{array}$ \\
\hline Present study & 15 & 5 years & 1. FA, 2. TA, 3. GM, 4. MH, 5. PT \\
\hline
\end{tabular}

In our study, epithelial CD117 labelling was significantly more prominent in FA-TA group than in other lesions. Additionally, we found positive stromal fibroblastic CD117 signalling which was correlated with the epithelial staining intensity for this marker $(\mathrm{r}=0.558, \mathrm{p}=0.031)$. This led us to think that stromal and epithelial expression of this marker might be interrelated and be affected by similar cellular pathways.

\section{CD34-breast cancer relationship and expression in fibroadenomas}

CD34 is a transmembrane glycoprotein (a sialomucin) that is thought to be involved in the modulation of cell adhesion and signal transduction and is expressed by mesenchymal cells at several sites, including the normal mammary stroma. The CD34-positive fibroblast in many organs is thought to represent an uncommitted cell capable of multidirectional mesenchymal differentiation and it has been suggested that there is an inverse relation between CD34 expression and myofibroblastic differentiation. Disappearance of CD34positive stromal cells consistently occurs in the stroma of invasive carcinoma of breast and most of the benign breast lesions comprising FAs express small to large numbers of CD34-positive stromal cells in the stroma. Adult FAs are known to express diffuse CD34 positivity in the stroma (8). All FAs in these studies exhibited diffuse strong CD34 expression in their stroma and phyllodes tumor (PT) showed variable and typically patchy distribution (9-12).
It has been suggested that malignant phyllodes tumor of the breast exhibited lower levels of CD34 expression than benign phyllodes or FAs (17).

All lesions but the BPT case in our study showed diffuse stromal staining for this marker.

\section{Phyllodes tumor (PT)}

PT is a rare tumor that may occur in women of all ages; $5 \%$ of these tumors occur in women younger than 20 years. In a study of 45 young females with this diagnosis, Rajan et al. found 34 benign and 11 malignant lesions in this category. After a follow up period of 58 months in 36 patients, they concluded that the lesion was not more aggressive in adolescent patients when compared to older women (18).

In the study of Silverman et al., 19 FAs and 7 PTs (5 low grade, 2 high grade) were evaluated for CD34 stromal staining and all FAs were shown to express diffuse CD34 positivity in the stroma while two of seven PT (1 low grade, 1 high grade) was negative for this marker (12).

In another study, 6 of 7 BPT stromal lesions stained positively for CD34 and only 1 of 7 BPTs, the stroma expressed CD117; while 9 of the 12 malignant PTs were composed of CD117 positive fibroblasts. They claimed that CD117 expression was associated with the malignant potential of PTs (19). Another study showed that epithelial staining was identified in $86 \%$ of BPTs (7). 
Our single case of BPT showed slightly weaker epithelial expression than FAs for CD117 and marked loss of CD34 when compared to other lesions (Figure 4). Although one case is insufficient to make conclusions, significant different expression patterns of CD117 and CD34 in BPT and FAs have led us to think that different oncogenetic pathways may be involved in these two groups of tumor.

\section{Gynecomastia}

There are very limited studies concerning CD117 expression on male breast. In one study while loss of epithelial c-kit expression accompanied female breast carcinoma, male carcinoma did not support this finding (20).

In another study, CD117 protein expression was analysed in proliferative lesions of human breast tissues in both sexes. This study showed that loss of c-kit product was related to malignant transformation in female breast, but not in the case of male breast. They suggested that the oncogenetic pathway of breast epithelium is different between males and females in terms of CD117 expression (20).

Our findings with CD117 expression was consistent with these findings being very weakly and focally in male breast epithelium when compared with female breast epithelium. It was suggested that different mechanisms of tumorigenesis may be involved in male and female breast epithelium regarding different expressions of this antigen (20).

As a result, the most commonly encountered lesion was FA and we showed that adolescent FAs and TAs did not differ in their expression patterns of c-kit and CD34. No differential expression of CD117 and CD34 was found between cellular and simple FAs. Male breast lesions and 1 phyllodes tumor express markedly low epithelial and stromal c-kit than FAs. Additionally there was marked loss of stromal expression of CD34 in the benign phillodes tumor case in the present study.

In conclusion, our study demonstrated that FA was the most common encountered breast lesion in childhood and adolescent FAs showed similar staining patterns for CD117 and CD34 as for adult counterparts and no visible cancer risk groups could be identified according to labelling for these antigens. Moreover, no atypical changes were recorded in any of the cases and epithelial hyperplastic changes was nonremarkable with focal typical ductal hyperplastic lesions in only 2 patients. Despite the limited number of cases in our series, different expression patterns of CD117 and CD34 between adenoma group and the gynecomastias and benign phyllodes tumor group may implicate different mechanisms of development and tumorigenesis among these groups. Finally, our series supports the findings of the study of Shehata et al that PASH is not uncommon in pediatric breast pathology being mostly positive in GM cases (21).

\section{REFERENCES}

1. Ruder EH, Dorgan JF, Kranz S, Kris-Etherton PM, Hartman TJ: Examining breast cancer growth and lifestyle risk factors: early life, childhood and adolescence. Clin Breast Cancer 2008, 8: 334-342

2. Dupont WD, Page DL, Parl FF, Vnencak-Jones CL, Plummer WD Jr, Rados MS, Schuyler PA: Long-term risk of breast cancer in women with fibroadenoma. N Engl J Med 1994, 331:10-15

3. Jayasinghe Y, Simmons PS: Fibroadenomas in adolescence. Curr Opin Obstet Gynecol 2009, 21:402-406

4. Dehner LP, Hill A, Deschryver K: Pathology of the breast in children, adolescents and young adults. Semin Diagn Pathol 1999, 16:235-247

5. Yared MA, Middleton L, Bernstam FM, Cristofanilli M, Sahin $A A$ : Expression of c-kit proto-oncogene product in breast tissue. Breast J 2004, 10:323-327

6. Eroglu A, Sarı A: Expression of c-kit proto-oncogene product in breast cancer tissues. Med Oncol 2007, 24:169-174

7. Djordjevic B, Hanna WM: Expression of c-kit in fibroepithelial lesions of the breast is a mast cell phenomenon. Mod Pathol 2008, 21:1238-1245

8. Chauan H, Abraham A, Philips JRA, Pringle JH, Walker RA, Jones JL: There is more than one kind of myofibroblast: analysis of CD34 expression in benign, in situ, and invasive breast lesions. J Clin Pathol 2003, 56:271-276

9. Kuroda N, Jin YL, Hamauzu T, Toi M, Miyazaki E, Hiroi M, Moriki T, Enzan H: Consistent lack of CD34-positive stromal cells in the stroma of malignant breast lesions. Histol Histopathol 2005, 20:707-712

10. Cimpean AM, Raica M, Narita D: Diagnostic significance of the immunoexpression of CD34 and smooth muscle cell actin in benign and malignant tumors of the breast. Rom J Morphol Embryol 2005, 46:123-129

11. Barth PJ, Ebrahimsade S, Ramaswamy A, Moll R: CD34+ fibrocytes in invasive ductal carcinoma, ductal carcinoma in situ, and benign breast lesions. Wirchows Arch 2002, 440:298-303

12. Silverman JS, Tamsen A: Mammary fibroadenoma and some phyllodes tumor stroma are composed of CD34+ fibroblasts and factor XIIIa+ dendrophages. Histopathology 1996, 29:411-419

13. Chung EM, Cube R, Hall GJ, Gonzales C, Stocker JT, Glassman LM: From the archives of the AFIP: breast masses in children and adolescents: radiologic-pathologic correlation. Radiographics 2009, 29:907-931

14. Tea MK, Asseryanis E, Kroiss R, Kubista E, Wagner T: Surgical breast lesions in adolescent females. Pediatr Surg Int 2009, 25 : 73-75

15. Samoilov MV, Bessmertnaia VS, Babichenko II: Immunohistochemical features of breast fibroadenomas. Arkh Patol 2007, 69: 41-43

16. Markopoulos C, Kouskos E, Mantas D, Kontzoglou K, Antonopoulou K, Revenas Z, Kyriakou V: Fibroadenomas of the breast: is there any association with breast cancer? Eur J Gynacol Oncol 2004, 25:495-497 
17. Moore T, Lee AH: Expression of CD34 and bcl-2 in phyllodes tumours, fibroadenomas and spindle cell lesions of the breast. Histopathology 2001, 38:62-67

18. Templeman C, Hertweck SP: Breast disorders in the pediatric and adolescent patient. Obstet Gynecol Clin North Am 2000, 27:19-34

19. Chen CM, Chen CJ, Chang CL, Shyu JS, Hsieh HF, Harn HJ: CD34, CD117, and actin expression in phyllodes tumor of the breast. J Surg Res 2000, 94: 84-91

20. Tsuura Y, Suzuki T, Honma K, Sano M: Expression of c-kit protein in proliferative lesions of human breast: sexual difference and close association with phosphotyrosine status. J Cancer Res Clin Oncol 2002, 128:239-246

21. Shehata BM, Fishman I, Collings MH, Wang J, Poulik JM, Ricketts RR, Parker PM, Heiss K, Bhatia AM, Worcester HD, Gow KW: Pseudoangiomatous stromal hyperplasia of the breast in pediatric patients: an underrecognized entity. Pediatr Dev Pathol 2009, 12:450-454
22. Inder M, Vaishnav K, Mathur DR: Benign breast lesions in prepubertal female children-a study of 20 years. J Indian Med Assoc 2001, 99:619-620

23. Sonmez K, Turkyilmaz Z, Karabulut R, Demirogullari B, Ozen IO, Moralioglu S, Basaklar AC, Kale N: Surgical breast lesions in adolescent patients and a review of the literature. Acta Chir Belg 2006, 106:400-404

24. Boothroyd A, Carty H: Breast masses in childhood and adolescence. A presentation of 17 cases and a review of the literature. Pediatr Radiol 1994, 24:81-84

25. Ciftci AO, Tanyel FC, Buyukpamukcu N, Hicsonmez A: Female breast masses during childhood: a 25 -year review. Eur J Pediatr Surg 1998, 8:67-70 